UDC 378-044.247(477:4)

DOI: 10.31470/2415-3729-2019-9-178-194

\title{
Higher Professional Education in the Conditions of Integration in European Educational Environment
}

\section{Olena Serhiichuk}

Doctor of Philosophy in History (Ph.D), Associate Professor, Associate Professor of the Department of Pedagogy Pereiaslav-Khmelnytskyi Hryhorii Skovoroda State Pedagogical University, $\bowtie$ 30, Sukhomlynskyi Str., Pereiaslav-Khmelnytskyi, Kyiv Region, Ukraine, 08401

E-mail: olenaserghijchuk@gmail.com

ORCID: 0000-0002-2008-1122

Date of receipt of the article: December 03, 2018 Article accepted for publication: February 22, 2019

\section{Вища професійна освіта в умовах інтеграції в європейський освітній простір}

\section{Олена Миколаївна Сергійчук}

кандидат історичних наук, доцент, доцент кафедри педагогіки ДВНЗ «Переяслав-Хмельницький державний педагогічний університет

імені Григорія Сковороди», $\triangle$ вул. Сухомлинського, 30, м. Переяслав-Хмельницький, Київська обл., Україна, 08401

Дата надходження статті: 03 грудня 2018 р. Стаття прийнята до друку: 22 лютого 2019 р.

\section{Abstract}

The article substantiates the priority tasks of reforming the system of higher education in Ukraine. The current state of higher professional education and its tasks are defined; the principles of 
modern European education are highlighted. Moreover, the components and functions of the organization of the educational process in higher education institutions are identified. The emphasis is placed on the development of pedagogical workers' professional and pedagogical excellence, the raise of the level of their readiness to use personal development and information and communication technologies, electronic learning tools, information and analytical systems for managing the development of vocational education and students' training. The recommendations of the European Higher Education Area regarding the development of higher education in the EU countries are substantiated. The author stresses that today one of the main principles of modern European education, which is responsible for the qualitative aspect of training and acquisition of professional competencies, is the mobility of students and teachers. It is noted that the influence of integration processes and the growing role of globalization cause the need to use the international educational standards in the field of education. The influence of reforming the system of higher education onto the creation of favorable conditions for the professional growth of a future specialist is substantiated.

Over the last years the improving of the higher education quality have occupied the dominating place in the issues of ensuring the competitiveness of Ukraine's educational system and training a personnel of a particullar qualification. The author also noted that the influence of integration processes, the growing role of globalization cause the need to use the international educational standards in the field of education. The impact of the higher education system reforming onto the creating of favorable conditions for the development of a person throughout its life, in particular, its professional growth, is theoretically grounded as the key to the development of national intellectual potential. The growing requirements for the quality of training specialists in proffesional education require further theoretical and practical development of the improvement of the system of higher professional education of Ukraine, its recognition in the European and world space, which will be an important step on the way to the professionalism of modern specialists. 
Key words: higher education institutions, vocational education, educational dominant, labor market, information society, directions of reforms in higher professional education, mobility of students and teachers, European Higher Education Area, Bologna Process.

\section{References}

1. Babyn, I. \& Lykova, V. Stratehiia ta suchasni tendentsii rozvytku universytetskoi osvity Ukrainy $v$ konteksti Yevropeiskoho prostoru vyshchoi osvity na period do 2020 $r$. [Strategy and current trends of the university education of Ukraine in the context of the European Higher Education Area up to 2020]. Retrieved from https://www.tempus.org.ua/uk/national-team-here/238strategija-ta-suchasni-tendenciji-rozvitku-universitetskoji-o sviti-ukrajini-v-konteksti-jevropejskogo-prostoru-vishhoji -osviti-na-period-do-2020-r-.html [in Ukrainian].

2. Bilyi, L.H. (2012). Osoblyvosti rozvytku vyshchoi profesiinoi osvity $v$ Ukraini ta suchasni tendentsii $v$ upravlinni osvitoiu. [Features of the development of higher professional education in Ukraine and current trends in the management of education]. Bulletin of the National Academy of the State Border Guard Service of Ukraine. Series: Pedagogical Sciences. Issue 1. Retrieved from https://www.irbis-nbuv.gov.ua/../cgiirbis_64.exe [in Ukrainian].

3. Drach, I.I. \& Chernyshova, Ye.R. (2010). Osoblyvosti osvitnoi diialnosti u suchasnii vyshchii shkoli [Features of educational activity in modern high school] Theory and methodology of education management, 3, 1-10. Retrieved from http: www.mode tme.umo.edu.ua/docs/ 3/10dramhc.pdfI [in Ukrainian].

4. Zharkova, O. (2017). Yakist pidhotovky zdobuvachiv vyshchoi osvity v umovakh modernizatsii osvity [Quality of the training of higher education applicants under conditions of education modernization]. Retrieved from http://er.nau.edu.ua/bitstream/NAU/2017/ [in Ukrainian]. 
5. Korzhuiev, A.V. \& Popkov, V.A. (2003). Tradytsyy y ynnovatsyy $v$ vblsshem professyonalnom obrazovanyy [Traditions and innovations in higher professional education.]. Moskva : INTRA [in Russian].

6. Natsionalna stratehiia rozvytku osvity v Ukraini na period 2012-2021 roky. [National Strategy for the Development of Education in Ukraine for the period 2012-2021.]. Retrieved from https://www.tempus.org.ua/../823-nacionalnastrategija-rozvitku-osviti-v-ukrajini-na-2012-2021-r-/244625_2013/.html [in Ukrainian].

7. Proekt Kontseptsii dualnoi osvity - Ministerstvo osvity $i$ nauky [Draft Concept of Dual Education - Ministry of Education and Science]. Retrieved from https://mon.gov.ua/../kontseptsii-dualnoi-osviti.doc [in Ukrainian].

8. Sergiichuk, O.M. (2018). Tendentsii rozvytku vyshchoi pedahohichnoi osvity v Ukraini na suchasnomu etapi. [Trends in the development of higher pedagogical education in Ukraine at the present stage]. Theoretical and didactic philology: Sb. sciences works. Series «Pedagogy». Pereyaslav-Khmelnytsky: «FOP Dombrovskaya Ya.M.», 27, 179-188 [in Ukrainian].

9. Dobroskok I., Dobroskok S. World Experience of Distance Learning as a Innovative Form of Professional Education. Professional Education: Methodology, Theory and Technologies. 2017, № (6), pp.7-26. URL https://education-journal.org/ index.php/ journal/article/ view/74.

\section{Вступ}

Євроінтеграційні процеси, що відбуваються в сучасному світовому освітньому просторі в контексті глобалізації, розвиток ринкових відносин, реформування вищої освіти в Україні зумовлюють посилення уваги до рівня підготовки кадрів професійної освіти. Завдання закладів вищої освіти полягає не лише в тому, щоб студенти оволоділи певною сумою знань для роботи за вибраним фахом, але й 
усвідомили шляхи подальшого розвитку власного професіоналізму та відповідно вміли інтегрувати знання, отримані в процесі навчання та самовдосконалення.

Національна стратегія розвитку освіти в Україні на 2012-2021 рр. акцентує увагу на виконання таких завдань: реформування освіти, як відродження національної системи освіти - найважливішої ланки у вихованні свідомих громадян української держави, формуванні освіченої, творчої особистості; виведення освіти України на рівень розвинутих країн світу. Сконцентрувавши увагу на самоосвіту та саморозвиток особистості, яка здатна критично мислити, та використовувати набуті знання й уміння для подальшого творчого вирішення власне професійних проблем (Національна стратегія розвитку освіти..., 2013).

Дослідження В. Андрущенка, М. Головатого, В. Журавського, В. Зайчука, В. Зайченко, В. Кременя, Л. Мулик розглядають педагогічні аспекти професійної освіти. 3'ясування готовності майбутніх фахівців до професійної діяльності досліджували М. Артюшина, В. Боброва, М. Головань, Л. Дибкова, А. Коржуєва, Л. Медведєва, О. Романовський, Н. Самарук та ін. Однак актуальність даної проблеми не вичерпує всіх аспектів теми дослідження. Перспективним вважаємо наукові пошуки у відстеженні новітніх світових освітніх тенденцій з метою прогнозування їхнього можливого впливу на систему вищої професійної освіти України.

Метою статті є аналіз реформування діяльності вищої професійної освіти в умовах інтеграції її в європейський освітній простір.

\section{Матеріал і методи досліджень}

Методи дослідження: теоретичні (аналіз та узагальнення психолого-педагогічної літератури), емпіричні (педагогічне спостереження, систематизація власного емпіричного досвіду роботи).

\section{Результати та їх обговорення}

Вища освіта в Україні нині є найважливішою сферою соціального життя для кожної людини. Важливість підвищення ii якості, проголошена у Законі України «Про 
освіту» (2017 р.), «Про вищу освіту» (2014 р.), у державній програмі «Освіта і навчання 2020», що свідчить про значну увагу до проблеми якості вищої професійної освіти з боку ЄС. Адже освіта нині формує інтелектуальний, культурний, духовний стан суспільства. Нині розуміння якості вищої освіти можна представити у вигляді наступної послідовності: носій знань; передача знань; сприйнятливість сучасних методик передачі знань; фундаментальність знань; затребуваність отриманих знань; використання отриманих знань у практичній діяльності (Жаркова, 2017).

У центрі освітнього процесу стоїть споживач знань здобувач вищої освіти. 3 метою отримання студентами закладів вищої освіти професійних компетенцій на період навчання виділяються наступні факти: насамперед це бажання вчитися протягом життя, важливість набутих знань на період навчання, знання іноземної мови та комп'ютерної техніки, розвиток інтелектуальних здібностей, обдарованість кожного, наполегливість, дисциплінованість, працездатність, спостережливість, планування кар'єри.

Освітня діяльність у закладі вищої освіти має грунтуватися на таких основних засадах:

- відповідність освіти потребам соціально-економічного розвитку суспільства на сьогодні;

- забезпечення інтелектуального розвитку особистості, оволодіння нею ефективними методами самостійної діяльності під час навчання;

- формування у молодих поколінь високих духовних, моральних, патріотичних, правових якостей на засадах загальнолюдських та національних цінностей;

- сприяння розвитку високої екологічної культури й відповідальності за збереження навколишнього середовища (Проект Стратегії реформування вищої освіти..., 2014).

На сьогодні метою професійної освіти є створення умов для оволодіння професійною діяльністю майбутніми фахівцями, зокрема одержання кваліфікації або перекваліфікації для включення молоді в громадську діяльність відповідно до ії здібностей та інтересів. 
Слід відмітити, що поняття «вища професійна освіта» враховує такі характеристики: вища професійна освіта передбачає підготовку фахівців певної кваліфікації; результатом професійного зростання майбутнього фахівця $\epsilon$ не лише рівень засвоєння студентами сукупності систематизованих знань, умінь і способів діяльності, що надають змогу в майбутньому самостійно і відповідально вирішувати поставлені перед ним завдання, здійснюючи власне професійне зростання, але й творчо використовувати у практичній діяльності досягнення науки, культури і техніки (Білий, 2012).

Досить неоднозначно у сучасній літературі на сьогодні визначаються основні функції вищої професійної освіти. Зокрема, А. Коржуєв і В. Попков вважають основними такі:

сформувати у майбутніх фахівців уміння цілісного сприйняття навколишнього світу та відчуття відповідної єдності з ним, а також цілісного сприйняття навчального процесу і результату діяльності, зокрема;

опанувати технології прийняття оптимальних рішень у професійній діяльності, уміння адаптуватися до різних змін у соціальному середовищі, прогнозувати перебіг розвитку тієї чи іншої ситуації, яка виникла під час діяльності, а також попереджувати негативні наслідки;

опанувати культурою системного підходу в навчальній діяльності та найважливіших загальнометодичних принципів iii організації, формування у майбутнього випускника закладу вищої освіти толерантності, стриманості, коректності у власних судженнях і подальшій професійній діяльності (Коржуєв, Попков, 2003: 8).

На сьогодні Державний стандарт вищої освіти України контролює кваліфікації та напрямки спеціальностей, за якими здійснюється підготовка фахівців у закладах вищої освіти за відповідними освітньо-кваліфікаційними рівнями, зокрема, загальні вимоги до кожного освітньокваліфікаційного і освітнього рівня.

На сьогоднішній день зміст вищої освіти визначається відповідно до вимог освітньо-кваліфікаційної характеристики фахівця (ОКХ), який характеризує його 
професійну діяльність і є складовою галузевого стандарту підготовки майбутнього фахівця з певної спеціальності. Зміст вищої професійної освіти представлено в освітньопрофесійній програмі (ОПП), що розкриває зміст освітньо-професійної підготовки майбутнього фахівця і $€$ складовою галузевого стандарту його підготовки 3 певної спеціальності, в якому зазначено перелік навчальних дисциплін 3 чітко визначеним обсягом навчального навантаження. Години, відведені на лекційні, практичні та індивідуальні заняття представлено у стандарті кожного закладу вищої освіти - навчальному плані.

Так, зокрема, Коржуєв А.В., та Попков В.А., у вищій професійній освіті вбачають заклад вищої освіти, який виконує функцію підготовки майбутнього фахівця до вирішення в подальшому його професійних завдань у певній сфері діяльності та передбачає достатньо високий рівень сформованості набутих здібностей, умінь і навичок, з метою подальшого їх удосконалення (Коржуєв, Попков, 2003: 9).

Важливою умовою у закладі вищої освіти залишається умова вдосконалення професійної підготовки, при якій студенти мають бути залучені до науково-дослідної діяльності, що містить мотиваційний, творчий, пізнавальний, ціннісно-орієнтований та результативний компоненти. 3 метою реалізації даної умови, слід передбачити посилення зазначених компонентів діяльності за рахунок включення у освітній процес підготовки усних i творчо-письмових доповідей і повідомлень студентів з мультимедійними та проектними технологіями, 3 технологією ситуаційного навчання.

Згодом, опановуючи обрану спеціальність у ЗВО, студенти мають виконувати завдання, які обирають вони самостійно їм пропонують викладачі, що відповідають наступним вимогам, зокрема:

- мають суспільно-корисну значущість даної проблеми;

- дані завдання відрізняються достатнім та високим рівнем складності;

- отримані в ході дослідження результати мають бути вагомими для подальшої їх освітньої діяльності; 
- потребувати від студентів активного залучення до теоретичних знань наукової, навчальної, методичної, довідкової й іншої літератури 3 метою розробки проекту;

- передбачати можливості групової та колективної діяльності (Драч, 2010: 5).

Одним із завдань, яке має вирішувати вища освіта на сьогодні - це виконання у процесі організації освітньої діяльності студентів настанови щодо неперервного здобування вищої освіти, яка потребує постійного оновлення i поповнення нових знань. Адже саме метою вищої професійної освіти в подальшому має стати не стільки наповнення студентами певним обсягом знань, а скільки формування в них усвідомленості необхідності проектування власного саморозвитку та самоосвіти, що $є$ підгрунтям майбутньої їх професійної діяльності.

Важливим залишається на сьогодні освітнім явищем в державі впровадження дистанційної освіти у закладах вищої освіти. Завдяки якій, розширюється можливість навчатися також абітурієнтів із особливими потребами. Адже у студента нині є скайп-зв'язок, інтернет та інше програмне забезпечення, яке дає доступ до необхідної навчальної інформації; студент матиме змогу спілкуватися з викладачем, отримувати відповідь на поставлені запитання. На сьогодні, такі інновації в освіті сприяють забезпечувати діалог між студентом та викладачем, організації освітнього процесу, застосовуванні різних прийомів та методів навчання.

Впровадження у заклади вищої освіти підготовки фахівців за дуальною формою навчання (відповідно до Проекту Концепції дуальної освіти) з 2018 року сприяє поєднання навчання осіб у закладі вищої освіти з навчанням на робочих місцях на підприємствах, в установах та організаціях з метою набуття студентами певної кваліфікації на основі укладеного ними договору. 3 метою покращення практичної підготовки майбутніх фахівців у Концепції підготовки фахівців за дуальною формою здобуття вищої освіти передбачається, насамперед, встановлення рівноправного партнерства закладів вищої освіти, 
роботодавців та студентів 3 метою набуття ними досвіду практичного застосування компетентностей та їх адаптація в умовах професійної діяльності. Важливо відрізняти дуальне навчання від традиційного проходження практики студентами та учнями. Дуальна форма освіти передбачає навчання на робочому місці з виконанням певних посадових обов'язків відповідно до трудового договору, що не слід спутувати 3 проходженням навально-виробничої чи педагогічної практики студентами. Саме така форма навчально-виробничої діяльності дає змогу майбутнім фахівцям швидше адаптуватися до робочого місця та знайти професію за покликанням (Проект Концепції дуальної освіти..., 2018).

Впровадження інтеграційних процесів у вищій професійній освіті України, значно зміцнює освіту, відкриває широкі можливості рейтингу закладів вищої освіти, з метою підготовки висококваліфікованих фахівців, єдиний простір вищої освіти в Свропі створює умови для вищої освіти України щодо співпраці між ЗВО, участі міжнародної співпраці у проектах студентів та викладачів.

Однією з першочергових проблем, що має вирішувати сучасна вища професійна освіта, $\epsilon$ проблема відбору обдарованої молоді до ЗВО, яка за період навчання має відображати всі особливості професійної діяльності майбутнього випускника в проекції на освітній процес.

Важливою проблемою залишається і відбір змісту вищої освіти, який нині грунтується на загальнодидактичних принципах (науковості, наочності, доступності, зв'язку навчання з життям тощо), які покликані регулювати процес відбору форм і методів, засобів організації освітньої діяльності у ЗВО. Слід наголосити, що окрім наведених принципів необхідно вводити у освітній процес закладу вищої освіти ще й такі: відповідності сучасного змісту освіти потребам ринку праці; єдності змістової і практичної сторін навчання; випереджального розвитку освіти у відповідності до вимог часу та ін. (Коржуєв, Попков, 2003: 7).

Нині, практика європейських держав показує, що при запровадженні національної системи забезпечення якості 
вищої освіти, надзвичайно важливо проявляти гнучкість та уникати сприйняття всіх стандартів і рекомендацій щодо інноваційних тенденцій в освіті, зокрема, створення агенції 3 академічного визнання і міжнародного обміну в рамках співпраці між студентами та викладачами; запровадження національної системи рейтингів закладів вищої освіти відповідно до Болонського процесу («Болонський процес 2020 - Європейський простір вищої освіти в новому десятиріччі» Льовен, 2009), що акцентує увагу на фундаментальній ролі університетів, акценту на дослідницькій та самоосвітній роботі (Бабин, Ликова, 2017).

Інтеграція системи вищої освіти України у Європейський простір вищої освіти (СПВО) відкриває такі можливості: зокрема, доступу до вищої освіти всіх бажаючих; широкої мобільності студентів, науковопедагогічних працівників; зміцнення позицій державних закладів вищої освіти на національному, європейському i світовому ринку праці та ринку освітніх послуг (Бабин, Ликова, 2017).

Таким чином, вимоги сучасності приводять до появи нових засобів і предметів праці, нових виробничих та інформаційних технологій, які наполягають на впровадженні у професійну освіту таких основних засад, зокрема: зміцнення «трикутника знань»: зв’язку між освітою, дослідницькою діяльністю та інноваціями в освіті; розвиток багатостороннього партнерства між закладами вищої освіти України та $€ C$; зміцнення зв'язків між вищою освітою та ринком праці (Жаркова, 2017).

Система вищої освіти України нині визначає такі тенденції, які невідомо чи сьогодні будуть на користь закладів вищої освіти, чи навпаки послаблять його діяльність, а саме: зростання вартості вищої освіти на заочній формі навчання на 15 відсотків, денній - 5\% (на прикладі ДВНЗ «Переяслав-Хмельницького ДПУ імені Григорія Сковороди»; зростання обсягу годин, який відводиться на самостійну роботу та практичну підготовку майбутніх фахівців; можливе збільшення обсягу навчальних предметів за вибором; встановлення оптимального поєднання 
теоретичної і практичної підготовки (з метою збільшення терміну навчально-виробничої та переддипломної практик), а також в зв'язку 3 малочисельністю навчальних груп перевага надається індивідуальним заняттям (Сергійчук, 2018: 184).

Досить важливим кроком у ЗВО сьогодні є навчання, стажування та дослідницька робота за кордоном, що збагачує індивідуальний досвід студента, надає йому можливість більше здобути фахових знань та дозволить розширити мережу контактів. Формування у майбутніх випускників умінь цілісного сприйняття оточуючого світу і відчуття єдності $з$ ним, поєднання професійної мобільності, що грунтується на відображенні у змісті освіти основ сучасних знань, наданню йому методологічної й світоглядної спрямованості, об'ємному відображенню навколишнього середовища і таким чином підготовки майбутнього фахівця у певній конкретній галузі, що передбачає набуття знань 3 обраної спеціальності, що є важливим аспектом нині у подальшій його професійній діяльності.

ДВНЗ «Переяслав-Хмельницький державний педагогічний університет імені Григорія Сковороди» 3 кожним роком намагається розширювати межі діяльності навчального закладу із 3ВО Чехії, Польщі, Туреччини, Німеччини, Китаю та ін. країн, у рамках академічного обміну студентами, співпрацю між навчальними закладами, участь у міжнародних проектах, спільна видавнича діяльність, організація спільних міжнародних науково-практичних конференцій, симпозіумів та інших заходів.

Щороку укладаються міжнародні угоди, між нашим ЗВО та міжнародними партнерами, метою яких $\epsilon$ забезпечення академічної мобільності студентів та адміністративного складу університету за програмою ЄС Еразмус+ (2016-2018 рр. між університетом імені Гарріка Масарика (Чехія) та (2016-2018 pp. між Гданським університетом (Польща), завдяки цим крокам студенти нашого університету матимуть змогу навчатися протягом одного семестру в партнерських вузах, а професорськовикладацький склад матиме змогу отримати новий досвід 
завдяки стажуванню у вказаних закладах вищої освіти. У 2018 році підписана угода про співпрацю із Стамбульським фондом науки і культури Туреччини 3 метою організації спільних проектів, напрацювань та заходів, обміну досвідом; а також договір про співпрацю в галузі науки і освіти 3 «Українсько-Китайським Центром Розвитку Культури i Освіти», який акцентує співпрацю на організації стажування викладачів, студентів та викладачів, студентів та молодих фахівців, що $є$ випускниками університету в Китаї та України.

Нові реалії України в контексті глобалізації та в умовах європейського вибору, зумовлюють заклади вищої освіти звернути увагу на формування освіченої творчої, конкурентоздатної особистості, чому слугує забезпечення пріоритетного розвитку особистості протягом всього життя, які включені до Закону «Про освіту» (2017 р.); вихід системи освіти в Україні на рівень систем освіти розвинених країн світу шляхом докорінного реформування його концептуальних, структурних i організаційних основ відповідно до Болонського процесу та «Свропи знань» 3 метою утворення єдиного узгодженого європейського простору вищої освіти для забезпечення світової конкурентоспроможності майбутніх фахівців - $\epsilon$ стратегічними пріоритетними завданнями реформування системи вищої професійної освіти в Україні.

\section{Висновки}

Отже, підвищення якості вищої професійної освіти посідає протягом останніх років домінуюче місце у питаннях забезпечення конкурентоспроможності освітньої системи нашої держави та підготовки кадрів відповідної кваліфікації. Важливість підвищення якості вищої професійної освіти сприяють впровадження дистанційної освіти та дуальної форми навчання у підготовці майбутніх фахівців, створення сприятливих умов 3 метою академічного обміну між студентами та викладачами у галузі співпраці та 3 метою розвитку особистості впродовж життя - на сьогодні набирають впевнених кроків i $\epsilon$ запорукою розвитку національного інтелектуального потенціалу. 
Зростаючі вимоги до якості підготовки фахівців 3 професійної освіти вимагають подальшої теоретичної та практичної розробки удосконалення системи вищої професійної освіти України та визнання іiі у європейському освітньому просторі.

\section{Література}

1. Бабин I., Ликова В. Стратегія та сучасні тенденції розвитку університетської освіти України в контексті Європейського простору вищої освіти на період до 2020 p. URL: https: //www.tempus.org.ua/uk/national-teamhere/238-strategija-ta-suchasni-tendenciji-rozvitku-universi tetskoji-osviti-ukrajini-v-konteksti-jevropejskogo-prostoruvishhoji-osviti-na-period-do-2020-r-.html/2017/

2. Білий Л. Г. Особливості розвитку вищої професійної освіти в Україні та сучасні тенденції в управлінні освітою. Вісник Національної академії Державної прикордонної служби України. Серія: Педагогічні науки. 2012. Випуск 1. URL: www.irbisnbuv.gov.ua/../cgiirbis_64.exe.

3. Драч I.I., Чернишова Є.P. Особливості освітньої діяльності у сучасній вищій школі. Теорія та методика управління освітою. 2010. №3. C.1-10. URL: http:// tme.umo.edu.ua/docs/3/10dramhc.pdf.

4. Жаркова О. Якість підготовки здобувачів вищої освіти в умовах модернізації освіти. URL: http:// er.nau.edu.ua/bitstream/NAU/2017/.

5. Коржуєв А. В., Попков В.А. Традиции и инновации в высшем профессиональном образовании. Москва : ИНТРА, 2003. $411 \mathrm{c}$.

6. Національна стратегія розвитку освіти в Україні на період 2012-2021 роки. URL: https://www.tempus.org.ua/../823-nacionalna-strategijarozvitku-osviti-vukrajini-na-2012-2021-r-/2446-25_2013/.html

7. Проект Концепції дуальної освіти - Міністерство освіти і науки. URL: https://mon.gov.ua/../kontseptsiidualnoi-osviti.doc 
8. Сергійчук О.М. Тенденції розвитку вищої педагогічної освіти в Україні на сучасному етапі. Теоретична i дидактична філологія: зб. наук. праць. Серія «Педагогіка». Переяслав-Хмельницький: «ФОП Домбровська Я.М.», 2018. Випуск 27. С. 179-188.

9. Dobroskok, I., \& Dobroskok, S. (2017). World Experience of Distance Learning as a Innovative Form of Professional Education. Professional Education: Methodology, Theory and Technologies, (6), 7-26. Retrieved from https://education-journal.org/index.php/ journal/article/ view/74.

\section{Сергійчук О.М.}

\section{Вища професійна освіта в умовах інтеграції в свропейський освітній простір}

\section{Анотація}

У статті обгрунтовано пріоритетні завдання реформування системи вищої освіти в Україні; висвітлено сучасний стан вищої професійної освіти та іiі завдання; висвітлено принципи сучасної європейської освіти; компоненти та функції організації навчального процесу у закладах вищої освіти; акцентується увага на розвитку професійно-педагогічної майстерності педагогічних працівників, підвищення рівня їхньої готовності до використання особистісно-розвивальних та інформаційнокомунікативних технологій, електронних засобів навчання, інформаційно-аналітичних систем управління розвитком професійної освіти і навчання студентів; обгрунтовані рекомендації Європейського простору вищої освіти щодо розвитку вищої освіти у країнах ЄС. Автор наголошує, що одним із основних принципів сучасної європейської освіти, що відповідає за якісний бік підготовки та надбання фахових компетенцій, на сьогодні $€$ мобільність студентів та викладачів. Зазначено, що вплив інтеграційних процесів, зростаюча роль глобалізації викликають необхідність 
використання міжнародних освітніх стандартів у сфері освіти. Обгрунтовано вплив реформування системи вищої освіти на створення сприятливих умов для фахового зростання майбутнього фахівця.

Ключові слова: заклади вищої освіти, професійна освіта, освітня домінанта, ринок праці, інформаційне суспільство, напрямки реформ вищої професійної освіти, мобільність студентів і викладачів, Європейський простір вищої освіти, Болонський процес.

\section{Сергийчук Е. Н.}

\section{Высшее профессиональное образование в условиях интеграции в европейское образовательное пространство}

\section{Аннотация}

В статье обоснованы приоритетные задачи реформирования системы высшего образования в Украине; освещено современное состояние высшего профессионального образования и ее задачи; освещены принципы современного европейского образования; компоненты и функции организации учебного процесса в учреждениях высшего образования; акцентируется внимание на развитии профессионально-педагогического мастерства педагогических работников, повышение уровня их готовности к использованию личностно-развивающих и информационно-коммуникативных технологий, электронных средств обучения, информационно-аналитических систем управления развитием профессионального образования и обучения студентов; обоснованные рекомендации Европейского пространства высшего образования по развитию высшего образования в странах ЕС.

Автор отмечает, что одним из основных принципов современного европейского образования, отвечающий за качественную сторону подготовки и приобретения профессиональных компетенций, на сегодня является мобильность студентов и преподавателей. Отмечено, что влияние интеграционных процессов, растущая роль 
глобализации вызывают необходимость использования международных образовательных стандартов в сфере образования. Обосновано влияние реформирования системы высшего образования на создание благоприятных условий для профессионального роста будущего специалиста.

Ключевые слова: высшие учебные заведения, профессиональное образование, образовательная доминанта, рынок труда, информационное общество, направления реформ высшего профессионального образования, мобильность студентов и преподавателей, Европейское пространство высшего образования, Болонский процесс. 